\title{
Her Dönem Geçerli Bir Kamu Yönetimi Modeli Müm- kün Mü?: Yönetim Kültürü Temelli Bir Perspektif
}

\author{
Alper ÖZMEN, Battal YILMAZ*
}

Her Dönem Geçerli Bir Kamu Yönetimi Modeli Mümkün Mü?: Yönetim Kültürü Temelli Bir Perspektif

Özet

Yönetim kavramına ilişkin teori ve metodolojiler, genel olarak evrensel kültür olduğu iddia edilen Batılı perspektifler üzerinden kurgulanmıştır. Bilindiği gibi kamu yönetiminde paradigma değişimi olarak ifade edilen "Yeni Kamu İşletmeciligii" kavramı dünyadaki tüm kamu yönetimi anlayışlarını radikal bir şekilde etkilemiştir. Evrensel bir model olarak pazarlanan bu yaklaşım ülkelerin yönetim kültürleri bağlamında ele alınmadığından dolayı birçok yerde yeni krizlere sebep olmuştur. Bu çalışmada her dönem geçerli bir kamu yönetiminin olabilirliği yönetim kültürü perspektifinden ele alınmıştır.

Anahtar Kelimeler: Yönetim Kültürü, Kamu Yönetimi, İsletmeci$\underline{\text { lik }}$

\section{Giriş}

Devletin hakim teması olan kamu yönetimi, MÖ 5000'lere kadar dayandırılmaktadır. Binlerce yıl boyunca, gruplar ve kabileler yani soy temelli siyasi örgütlenme biçimleri şeklinde ortaya çıkan yapılar, eski Mısır ve Mezopotamya'daki ilk arkaik devletlerin takip ettiği giderek daha karmaşık hale dönüşen merkezi hükümet biçimlerini doğurmuştur (Carneiro, 1970, s. 733; Petersen and Skaaning, 2010, s. 202).

Söz konusu tarihin ilk dönemlerinde devletler kuran Sümer, Mısır, Çin, Hint gibi uygarlıklar her ne kadar hukuki biçimde örgütlü olmasa da bir kamu yönetimine sahip olmuşlardır. Çivi yazısı ile

*Alper ÖZMEN, Doç.Dr., Eskişehir Osmangazi Üniversitesi, Siyaset Bilimi ve Kamu Yönetimi Bölümü, aozmen@ogu.edu.tr , ORCID ID orcid.org / 0000-0002-4185-4382; Battal YILMAZ, Doç.Dr., Kırşehir Ahi Evran Üniversitesi, Siyaset Bilimi ve Kamu Yönetimi Bölümü, battalyilmaz40@hotmail.com, ORCID ID orcid.org / 0000-0003-4792-5505 
çeşitli kayıtları tutan Sümerler; birçok ademi merkeziyetçi şehir devleti kurmuşlardır (Nişancı, 2015). Bu dönemde devlet içerisinde oluşturulmuş yasal-rasyonel ilkelere dayanan bir kamu yönetimi teşkilatı söz konusu değildir.

Kamu yönetiminin gelişiminde siyaset, yönetim ve ahlak üzerine çalışmalar yapan Sokrat, Aristo, Platon, Machiavelli, İbn-i Haldun, Yusuf Has Hacib, Nizam'ül Mülk, Farabi, Kınalızade Ali Efendi gibi ilk ve ortaçağ filozoflarının da önemli katkıları olmuştur. Antik dönemde kentin rolü ve organizasyonu hakkındaki tartışmalar, kentin nasıl yapılandırılması ve yönetilmesi gerektiğine ilişkin görüşler ilkçağ filozofları tarafından ortaya konulurken (Tatulescu, 2013, s. 74); devlette ve yöneticide bulunması gereken nitelikler, iyi yönetimin unsurları gibi hususlar özellikle Türk-İslam düşünürleri tarafından açıklanmıştır.

Modern devletin egemenlik aracı olan kamu yönetiminin bürokrasiye dayandırıması (Burns, 1980, s. 494), endüstri devrimi, kapitalizmin yükselişi ve ulus devletlerin bürokratik olarak örgütlenmesi birbirleriyle ilişkili gelişmelerdir. Zira kapitalizmin temelinde var olan "etkinlik, ekonomiklik ve verimlilik" faktörleri, esasen bürokratik ilke ve prensiplerle organize olmuş bir devlet yapısı içinde ortaya çıkmaktadır (Parlak ve Doğan, 2016, s. 55; Livioara, 2009, s. 127).

18. yüzyılın ilk yarısında, Almanya ve Avusturya'nın mutlakıyetçi hükümdarlarına hizmet etmek için tasarlanmış, aynı zamanda kamu görevlilerinin eğitimini de kapsayan merkezi ve sofistike bir kamu idaresi anlayışı olarak ortaya çıkan Kameral Bilimler kürsüleri, kamu yönetimi disiplininin doğuşunun ana öncüsü olarak ifade edilmektedir (Spicer, 1998, s. 149). 1812 yllında Fransa'da Charles-Jean Bonnin, önceki geleneklerden kopan ilk kişi olarak "idareyi bir bilim olarak ele alma” iddiasında bulunarak, kamu yönetiminin sistematik ve betimleyici bir çalışmasının gerekliliğini vurgulayan Kamu Yönetiminin Illkeleri adlı eseri yayınlamıştır (Chevallier, 1996, s. 68). Almanya'da Lorenz Von Stein (1815-1890), kamu yönetimini bir teori olarak kabul etmekte, teori ve pratiğin bütünleştirilmesinden bahsetmekte ve ayrıca kamu yönetiminin bilimsel yöntem olarak benimsenmesinin gerekliliğini vurgulamıştır (Thornhill and Dijk, 2010, s. 99). Woodrow Wilson'ın 1887'deki "Politicial Science Quarterly" dergisinde yayımlanan "The Study of Administration” (Yönetimin İncelenmesi) isimli makalesi onu kamu yönetimi bilimini önemli olarak değerlendiren ilk kişi yapmıştır. Wilson'ı, kamu yönetimi ile ilgili Von Stein'dan daha etkili yapan faktörler, makalesinde; siyaset yönetim ayrımını vurgulaması, yönetimi mesleki perspektifle ele alması, siyasi ve özel kuruluşlar ile siyasi yapılar arasında karşılaştırmalı analizler yapması ve kamu görevlilerini eğiterek etkin yönetim sağlama ve kalitelerini değerlendirme konusundaki düşünceleri olmuştur (Thornhill and Dijk, 2010: 99). Bu düşünürlerden başka Frederick Taylor, Henri Fayol ve Luther Gulick'in görüşlerinin kamu yönetiminin gelişiminde önemli katkıları olduğu bilinmektedir. Ayrıca Frank Goodnow, Leonard D. White ve W. F. Willoughby de kamu yönetimi öğretisinin gelişiminde büyük etkileri olan isimler olarak vurgulanmaktadırlar (Eryılmaz, 2018, s. 36-42; Ergun, 1997, s. 5-6).

Geleneksel yönetim anlayışı, Wilson'un "Yönetim-Siyaset Ayrımı”, "Taylor'ın "Bilimsel Yönetim Yaklaşımı” ve Weber'in "ideal Bürokrasi” felsefesi kapsamında 19. yüzyılın başından 20. yüzyılın 
son çeyreğine kadar hakim paradigma olarak kamu yönetiminde ağırlığını hissettirmiştir (Leblebici, 2001, s. 15). Taylor, Bilimsel Yönetim Yaklaşımı'nda rutin işlerin yerine getirilmesinde insan faktörünün makinelere ek olarak etkin olarak kullanılabilmesini açıklarken; Fayol, Yönetim Süreci; Weber'de Bürokrasi Yaklaşımında formel organizasyon yapısını ayrıntılı olarak ele almıştır. Bu bağlamda geleneksel yönetim teorisi, açık ve seçik olarak belirlenmiş bir örgüt yapısı ve otorite ilişkileri ile etkinlik ve verimliliğin nasıl arttırılabileceği konusuyla ilgilenmiştir (Koçel, 2003, s. 195).

II. Dünya Savaşı sonrası kamu yönetimi için bir kriz dönemini ifade etmiştir. Üçüncü Dünya Ülkelerinde kurumsal yönden görülen farklılıklar, kamu yönetimi alanına ilişkin o zamana kadar yapılan genellemelerin yanlışlı̆ııı göstermiştir. Kamu yönetiminin siyaset biliminden ayrımasının önemli bir yanılgı olduğu eleştirilerinin artmasına sebep olan söz konusu gelişmeler "kamu yönetiminde kimlik krizi” doğurmuştur. 1960'lı yıllarda sosyal bilimler alanındaki gelişmeler, diğer bilim dallarındaki araştırma yöntemlerinin kamu yönetimi için de geçerli olmasını sağlamıştır. Söz konusu gelişmeler kapsamında genel yönetim vurgusu ön plana çıkmış ve yönetimin kamu ve özel sektörde uygulamalarının benzer olduğu fikri gündeme getirilmiştir (Leblebici, 2004, s. 9-10). Kamu yönetiminin mevcut kimlik krizini daha çok derinleştiren bu düşünceler yeni hareketlerin gelişmesine zemin hazırlamıştır. 1968'de Yeni Kamu Yönetimi Hareketi ile başlayan reform arayışları, 1980'lerde Yeni Kamu İşletmeciliği üzerinden farklı bir kulvara evrilmiş ve bundan sonra ortaya çıkan anlayışlar Yeni Kamu İşletmeciliğinin eksik veya hatalı yönlerini tamamlama ya da karşı argüman geliştirme şeklinde sürdürülmüştür.

Bu çalışmada nitel araştırma yöntemi kullanılmıştır. Literatür incelemesinde Yeni Kamu Yönetimi Hareketi, Yeni Kamu İşletmeciliği, Yönetişim, Yeni Kamu Hizmeti, Neo Weberyen Devlet, Kamu Değeri gibi yaklaşımların açıklamasına yer verilmiş ve daha sonra yönetim kültürü kavramı açısından değerlendirme yapılmıştır.

\section{Yeni Yönetim Yaklaşımları}

Batıda kamu yönetimi disiplininin gelişimine yönelik akademik çalışmalar, genel olarak dünyadaki tüm hükümetlerin ve yönetim şekillerinin aynı politikaları ve uygulamaları benimsedikleri yanılgısı üzerine kurgulanmıştır. Bu tekdüzelik inancından kaynaklanan anlayış, tüm toplum ve kültürlerde geçerli kamu yönetimi reformları oluşturulması sonucunu doğurmuştur. Sonuç olarak da ülkelerde toplumun kültürel normlarıyla uyuşmayan, ihtiyaç ve beklentilerine cevap vermeyen yönetim tür ve yapıları oluşmuştur. Bu çalışmada 1960 'ların sonlarından itibaren kamu yönetiminin sorun ve çıkmazlarına çözüm olarak sunulan; yönetim kültürleri dikkate alınmadan, büyük bir kısmı evrensellik iddia eden yönetim yaklaşımlarından bahsedilerek yönetim kültürü üzerinden değerlendirme yapılacaktır. Bu başlık altında yeni yönetim yaklaşımları hususunda sınırlandırmaya gidilmiş ve yalnızca Yeni Kamu Yönetimi Hareketi, Yeni Kamu İşletmeciliği, Yönetişim, Yeni Kamu Hizmeti, Neo Weberyen Devlet, Kamu Değeri gibi yaklaşımlar esas alınmıştır. 


\subsection{Yeni Kamu Yönetimi Hareketi ${ }^{1}$ (New Public Administration Movement)}

ABD için 1960'lı yılların sonlarından 1980'lere kadar yaşanan dönem siyasi, idari, sosyal ve diğer birçok alanda kırımaların ve dönüşümlerin yaşandığı, Waldo'nun ifadesiyle "türbülans" yıllarıdır. ${ }^{2}$ Bu dönem, Siyaset Bilimi ve Kamu Yönetiminin derinden etkilendiği, geleneksel kamu yönetimi anlayışının eksik, kusurlu yanlarının sorgulandığı; çözümsüzlük ürettiği iddialarının yükseldiği bir zaman dilimi olarak tanımlanabilir (Özgür ve Öztepe, 2015, s. 98).

Popüler olarak Minnowbrook Perspektifi olarak da adlandırılan Syracuse Üniversitesi Minnowbrook Konferansı (1968) sırasında kavramsallaştııımış olan Yeni Kamu Yönetimi (YKY), alternatifler sağlayamasa da, geleneksel teorilerdeki anomalileri vurgulayarak, kamu yönetimi çalışmalarına ve paradigmasına alternatif bir bakış açısı sağlamıştır. Bu perspektiften ortaya çıkan; kamu yöneticilerinin yalnızca politika uygulamasından değil aynı zamanda politika oluşturmadan da sorumlu olmaları ve dolayısıyla kamu yönetiminin sınılarını genişletmesi gerektiğidir (Thornhill and Dijk, 2010, s. 103).

Yeni Kamu Yönetimi Hareketi (YKYH), "yeni" bir kamu yönetimine ihtiyaç duyulmasından hareketle geleneksel yönetim anlayışının işlemeyen, problemlere çare bulamayan yapısına karşı bir akım olarak ortaya çıkmıştır. Öncülüğünü Waldo ve öğrencilerinin yaptığı Minnowbrook Toplantılarıyla yeşeren hareket, 1968 yılındaki ilk konferansında kamu yönetiminin siyaset biliminden ayrı bir disiplin olduğunun altını çizerek; sosyal adalet, eşitlik, hakkaniyet gibi kavramları kamu yönetiminin merkezine oturtarak; vatandaşlık, kamu hizmeti ve idari devletin demokratik değerler açısından önemini vurgulamıştır (maxwell.syr.edu.tr, 2019). Genel olarak kendisini Minnowbrook Toplantılarıyla tanıtan hareket, ekonomi ve verimlilik merkezli baskın kamu yönetimi anlayışının reddine dayanmaktadır. İnsan ve demokrasiyi göz ardı eden, temsil sorununu gündeme getiren söz konusu baskın düşünceden Waldo'nun ifadesiyle "daha liberal ve Marksist olmayan sola doğru yönelim" hedeflenmiştir. Yeni Kamu Yönetimi Hareketi anlayışının temel değeri katılım aracılığıyla sağlanacak olan sosyal adalettir. Amerika için yabancı bir kavram olarak görülen, gerekli önem verilmeyen sosyal adalet, YKY hareketine göre çelişkili bir şekilde özel girişim eksenli sistemin Amerikan siyasal yaşamında muhafazasıyla birlikte ele alınmıştır (Sayman, 2006, s. 77-78). Minnowbrook Konferansları, 20 yıl arayla günümüze kadar toplam üç konferans olarak düzenlenmiştir.

\footnotetext{
${ }^{1}$ Yeni Kamu Yönetimi, ABD kökenli bir harekettir. ABD’nin kendi içyapısı çerçevesinde yaşadığı askeri, toplumsal, siyasal, çevresel, demografik krizler yine kendi vatandaşlarının hükümet ve kamu kurumlarına olan güven ve bağlılığını ciddi anlamda sarsmıştır. Bu çalkantılı dönem kamu yönetimi alanında çalışan genç akademisyen ve uygulayıcıları yeni çözümler aramaya yöneltmiştir.

2 Waldo'ya göre, 1960'lar ve 1970'lerin sonlarında ortaya çıkan toplumsal ve siyasal çalkantılardan kaynaklanan bu hareket, gençlerin bir isyanı ve Marksist olmayan solun karşı kültürünün bir parçasıydı (Fry and Raadschelders, 2017: s. 417).
} 
II. Minnowbrook Konferansı, önceki dönemde ele alınan konuları yeniden değerlendirmek, yeni dönemle mukayese yapmak, kamu yönetiminin geleceğine ilişkin düşünceleri ortaya koymak amacıyla 20 yıl sonra 1988'de George Frederickson başkanlı̆̆ında gerçekleştirilmiştir. Konferansta kamu yönetimi araştırma ve uygulamasına yön verecek nitelikli konular dikkat çekmiştir (Özer, 2014, s. 22). Illk konferansta tartışılan sosyal ve güncel sorunlarla ilgili olma, pozitivizm karşıtlığı, bireysel erdem ve ahlak, demokrasi ile kamu yönetimini uzlaştırma, müşteri temelli sorumluluk, sosyal eşitlik gibi konuların büyük bir kısmı ikinci toplantının da konusu olmuştur. II. Konferans daha teknik ve bireysel, yaş ve cinsiyeti de içeren bir sosyal eşitlik anlayışına dayanmakta; verimliliği ve performans yönetimini önemsemekte; sosyal bilimler ile pozitivist ve davranışçı perspektifleri içermektedir. Bu konferansın düzenlendiği dönemin olumsuz yönü, Yeni Kamu İşletmeciliğinin yükseldiği, popülaritesinin arttığı bir tarihe denk gelmesidir. 1980'li yıllarda Ronald Reagan'ın sahip olduğu idari, siyasi, felsefi görüşler devlet ve bürokrasi karşıtı yeni sağ fikrine dayandığından II. Konferans ilki ile aynı doğrultuda seyretmemiştir. Devletin küçültülmesi, özelleştirmeler, özel yararın kamu yararından üstün görülmesi, kamu yönetiminde işletmecilik anlayışı gibi radikal değişiklikler düşünce ayrılıkları oluşturmuştur (Özgür ve Öztepe, 2015, s. 105-106).

Üçüncü Minnowbrook Konferansı ise 2008 Eylül ayında ilk konferansın 40. yıldönümünde aynı şekilde yine genç 50 akademisyenin davet edilerek, günümüz kamu hizmetlerinin kriz ve türbülanslara nasıl cevap verebileceği üzerine tartışmayı içermektedir. "Kamu Yönetiminin Geleceği" ana tema olarak belirlenmiş ve dünyada kamu yönetimi ve kamu hizmeti anlayışı şeklinde iki başlık altında incelenmiştir. Konferansta doktorasını yeni tamamlamış 55 katılımcı ile birlikte 13 ülkeden 200'den fazla akademisyen ve uygulamacı da bulunmuştur. Akademisyen-uygulayıcı ilişkisi, yönetişim, demokratik performans yönetimi, mali yönetim, küreselleşme, karşılaştırmalı analizler, bilgi teknolojileri ve yönetimi, hukuk, siyaset- yönetim ilişkisi, liderlik, disiplinler arası yaklaşımlar, ağlar, kamu yönetimi değerleri ve teorisi, sosyal eşitlik ve adalet, açıklık, sorumluluk ve hesap verebilirlik, yeni nesil kamu görevlilerinin eğitimi gibi konular tartışılmıştır (akt. Özer, 2014, s. 22-23).

YKYH, etkili bir hareket olmasına rağmen etki sahası düşük kalmıştır. Evrensellik iddiasının olmaması, gösterilen ilginin sınırlı olması sonucunu doğurmuştur (Özgür, 2003, s. 216).

\subsection{Yeni Kamu İşletmeciliği (New Public Management)}

1980 sonrası kamu yönetiminde ortaya çıkan evrensel idari reform hareketleri, bir yandan uluslararası ekonomik sistemde meydana gelen değişiklikler, diğer taraftan da ulusal siyasi sistemlerde devlet hizmet ve düzenlemelerine ilişkin sınırsız taleplerin yol açtığı mali streslerden kaynaklanmıştır. Bu stresler, bütçe kısıtlamalarını ve hükümetlerin kamu hizmetlerini küçültmeyi amaçlayan politikalarının yanı sıra devlet faaliyetlerini özelleştirmek ve özel sektör işletmelerini serbest bırakmak için çeşitli önlemlerin alınmasına yol açmıştır (Aucoin, 1990, s. 115). Yeni Kamu İşletmeciliği (YKi) bu bağlam da 1970'lerin sonu ve 1980'lerin başında gündeme gelmiştir. Illk uygulayıcıları Ingiltere'de Margaret Thatcher, ABD'de Ronald Reagan olmuş, ardından Yeni Zelanda ve Avustralya hükümetleri de harekete katılmıştır. YKi idari reformlarının bu ülkelerdeki başarı hikayeleri 
sonrasında akademisyenler, söz konusu idari reformların ortak özelliklerini belirleyerek Yeni Kamu İşletmeciliği etiketi altında düzenlemişlerdir (Gruening, 2001, s. 2).

1980'lerin başlarında, Peters ve Waterman'ın işletmelerde mükemmel yöneticilik uygulamalarını tanımladıkları "Mükemmellik Arayışı: Amerika'nın En İyi İşletmelerinden Dersler" isimli eseri mevcut yönetsel sahneyi değiştirmiştir. Peters ve Waterman, başarı için organik yapılar, insancıl stratejiler ve liderlik etmek için güçlü bir örgüt kültürünün önemini vurgulamışlardır. Bu dönemde mükemmellik arayışı kapsamında yoğun bir kamuoyu tartışması başlamış ve kısa sürede bu hareket kamu yönetiminde yayılma göstermiştir. Daha fazla sayıda bilim adamı Peters ve Waterman'ın ortaya koyduğu felsefeyi kamu kuruluşlarına uyarlayarak mükemmelleştirmenin mümkün olup olmayacağını tartışmaya açmıştır. Bu bağlamda liderlik, misyon, kültürel odaklı stratejik yönetim gibi kavramların yanı sıra özel sektör kuruluşlarında uygulanan Toplam Kalite Yönetiminin kamu yönetimine uyarlanması suretiyle başarılı ve verimli örgütlerin oluşturulması fikri önem kazanmıştır (Gruening, 2001, s. 11).

Bu dönemde gelişen neoliberal teoriler kapsamında özelleştirme (privatization), serbestleşme (deregulation) ve liberalleşme kamu yönetiminde de etkili olmuştur. IMF ve Dünya Bankası gibi uluslararası kuruluşlar kredileriyle birçok ülkede yaptıkları çeşitli yatırımlarla YKI anlayışını desteklemişlerdir. Neoliberal teoriler ve YKi, devletin başarısızlı̆̆ı, verimsiz ve hantal olarak çalıştı̆̆ı, bürokratik yapıların gereksiz kamu harcamalarına sebep olduğundan kamu hizmetlerinin pahalılığı eleştirileri üzerinden yükselmişlerdir. Bu eleştiriler sonucunda kamu sektörünün de özel sektörde uygulanan yöntem ve usullere göre çalışması düşüncesi ortaya çıkmış ve kamu hizmetlerinin ticarileştirilmesi ve özelleştirilmesi söz konusu olmuştur (Tarhan ve Ezici, 2011, s. 17). Guy Peters'a göre YKi, verimliliğini artırmak isteyen hükümetler tarafından denenmiş bir dizi reformu içermektedir. YKi yaklaşımları daha fazla katılım, esneklik ve deregülasyonu ve piyasa mekanizmalarının kullanımını intiva eder. Belki de yeni tekniklerin en baskın teması, kamu sektöründe performansı arttırmak için piyasa mekanizmalarını kullanma girişimidir. Bu, eskiden hükümet tarafından gerçekleştirilen işlevlerin özel sektöre veya iş kuruluşlarına devredildiği özelleştirmeyi kapsamaktadır (akt. Pfiffner, 2004, s. 446).

"Yeni Kamu İşletmeciliği" kavramsallaştırması ilk defa İngiliz akademisyen Christopher Hood'un "A Public Management for All Seasons" başlıklı çalışmasında yer almış ve iki kuramsal temele dayandırımıştır. Bunlar, Kamu Tercihi ve İşlem Maliyeti Kuramlarını kapsayan "Yeni Kurumcu İktisat" teorisi ve "İşletmecilik (managerialism)" yaklaşımıdır. Bu bağlamda iktisat ayağı ile kamu yönetiminde rekabete dayalı, müşterilerin tercih hakkının bulunduğu, açık ve inisiyatif sahibi bir yönetim oluşturmaya yönelik bürokratik reform hareketleri, teorik bir temele oturtulmuştur. İşletmecilik ayağıyla da kamu sektöründe işletme yönetimi teori ve pratiklerinin hakim kılınması, sonuç odaklı, maliyet bilinçli, yöneticilerin risk ve sorumluluk üstlendiği bir yapı oluşturulmak istenmiştir (Hood, 1991, s. 5). 
Hood (1991, s. 4-5) YKi'yi yedi özellik üzerinden açılamaktadır. Bunlar; kamu sektöründe profesyonel yönetici; açık standartlar ve performans ölçümü; süreçlerden çok sonuçların kontrolüne odaklanma; kamu sektörünün optimal birimlere ayrılması; kamu sektöründe rekabetin arttırıması; kamu yönetiminde özel sektör yöntem ve tekniklerinin uygulanması; kaynakların kullanımında daha fazla disiplin ve tutumluluktur.

Yeni Kamu İşletmeciliği terimi, geleneksel kamu yönetimi modelinde var olan verimsizliklerin üstesinden gelmeyi amaçlayan çok çeşitli teknikleri ve bakış açılarını kapsamaktadır. Robert Behn, Yeni Kamu İşletmeciliğini "kamu sektörünün performansını arttırmaya çalışan tüm taktik ve strateji koleksiyonları” olarak tanımlamaktadır. YKi'nin başlangıç noktası, 20. yüzyılın sanayileşmiş ekonomilerinde kullanılan geleneksel bürokratik yapıların o döneme özgü olduğu ve günümüzde etkisini yitirmiş olduğunun anlaşılmasına dayanır. Geleneksel sistemin büyük boyutlu ve katı yapılarının, bilginin anlık yayıldığı iletişim çağında ve ekonomik değerin bilgiye ve endüstriyel üretimden ziyade manipülasyona dayandığı bir ekonomi için başarı ortaya koyması güç gözükmektedir. Elbette, üretim hala önemini korumakla birlikte giderek daha fazla bilgi sistemlerine dayanmaktadır. Çalışanların davranışlarını hiyerarşik olarak kontrol etmek, hizmet sunumunun yavaşlamasına, yeterince hızlı tepki verememesine sebep olmaktadır. Bu nedenle YKi, adem-i merkeziyetçi yani merkezi olmayan yönetim, yöneticilere takdir yetkisi, mal ve hizmetlerin üretim ve sunumu için sözleşme yöntemi, performansın arttırılması için rekabet, vatandaşın yerine müşteri kavramı ve bürokrasi yerine piyasa mekanizmalarının kullanılmasından yanadır. Aynı zamanda YKi, girdileri muhasebeleştirmek yerine sonuçların ölçülmesi ile hesap verebilirliği sağlamayı amaçlamaktadır. Performans ölçütleri; kurallar ve düzenlemeler ile baştan sona sıkı kontrolün yerini alacaktır. Bu anlayışa göre, yöneticilere yönetmeleri için daha fazla takdir yetkisi verilmeli, performanslarından sorumlu tutulacaklarsa, kararlarını kullanma esnekliğine sahip olmaları sağlanmalıdır (Pfiffner, 2004, s. 445-446).

YKI, özel sektör yönetim tekniklerinin ve piyasa mekanizmalarının kamu sektörünün verimliliğini artırdığı fikrinden ilham alan bir dizi reformu yakalayan bir etikettir. YKi tipi reformlar arasında, performans yönetimi sistemlerinin tanıtılması, kamu yöneticilerinin sorumluluğundaki artış, kamu sektörüne piyasa mekanizmalarının tanıtılması, kamu sektöründe daha fazla rekabet, kalite yönetimi tekniklerinin tanıtılması yer almaktadır (Maesschalck, 2004, s. 465).

Donald Kettl, YKi yaklaşımının amacını "hiyerarşik olarak yapılandııılmış ve otorite ile yönlendirilmiş geleneksel bürokrasinin patolojisine bir çare" ve "otorite odaklı hiyerarşik sistemleri kökten çıkarma" olarak ifade etmektedir. Ayrıca YKi yaklaşımının altı temel özelliğini şöyle özetlemektedir: verimlilik, piyasalaştırma, hizmet yönelimi, ademi merkeziyetçilik, politika yönelimi ve sonuçların hesap verebilirliği (akt. Pfiffner, 2004, s. 447). Thompson ve Thompson da, YKİ yaklaşımının “öncelikle işletme yönetimi literatüründen ödünç alındığını, kaynakları kullanmak için daha fazla yönetim serbestisi, girdilerden ziyade sonuçlara odaklanma ve hizmet sunumu için özel sektöre daha fazla güven duyma" çağrısında bulunduğunu ileri sürmektedir (akt. Pfiffner, 2004, s. 447). Bahsedilen tüm bu unsurlarıyla YKi’nin, yönetim kültürlerini dikkate almadan, ülkelerin kamu yönetimlerini radikal bir biçimde dönüştürmeyi hedefleyen, evrensellik iddiası olan bir paradigma olduğu söylenebilir. 


\subsection{Yönetişim (Governance)}

1980'lerde uygulamaya konulan neo-liberal politikaların devlete ait yetkileri devre dışı bırakması ve bunun ardından birçok ülkede meydana gelen işsizlik, yoksulluk, yüksek enflasyon; 1990 'lardan itibaren söz konusu politikaların devlete ilişkin yeni bir formülasyon oluşturmasına sebep olmuştur. Illk kez 1989 yılında Afrika'da Sahra Altı Ülkelere yönelik hazırladığı raporuyla Dünya Bankası, yönetişim kavramını ileri sürmüştür. Devletin rolünü yeniden tanımlama, bu dönemde yönetişim kavramıyla sürdürülmüştür.

Yönetişim, hükümetlerin ve diğer sosyal organizasyonların kısmen nasıl etkileşimde bulundukları, vatandaşlarla nasıl ilişki kurduğu ve karmaşık bir dünyada kararların nasıl alındığı ile ilgilidir. Bu yönüyle, toplumların veya kuruluşların önemli kararlarını aldıkları, sürece kimlerin dahil olduğunu ve nasıl hesap verdiklerini belirleyen bir süreçtir (Graham vd., 2003, s. 1). Dünya Bankası'na göre yönetişim, bir ülkenin ekonomik ve sosyal kaynaklarının yönetiminde gücün uygulanma şekli olarak tanımlanır. Dünya Bankası, yönetişimin üç farklı yönünü tanımlamıştır: (i) siyasi rejim formu; (ii) bir ülkenin kalkınma için ekonomik ve sosyal kaynaklarının yönetiminde otoritenin kullanıldığı süreç; ve (iii) hükümetlerin politika işlevlerini tasarlama, formüle etme ve uygulama kapasitesi (Weiss, 2000, s. 797).

BM Kalkınma Programı (UNDP) yönetişim kavramını, bir ülkenin işlerini her düzeyde yönetmek için ekonomik, politik ve idari otoritenin kullanılması şeklinde tanımlamaktadır. Buna göre yönetişim, vatandaşların ve grupların çıkarlarını ifade ettikleri, yasal haklarını kullandıkları, yükümlülüklerini yerine getirdikleri ve farklılıklarına aracılık ettikleri mekanizmaları, süreçleri ve kurumları içerir. Ekonomik İşbirliği ve Kalkınma Örgütü (OECD)'ye göre yönetişim kavramı, sosyal ve ekonomik kalkınma için kaynakların yönetimi ile ilgili olarak bir toplumda siyasi otoritenin kullanılmasını ve kontrolün sağlanmasını ifade eder. Ottawa Yönetişim Enstitüsü, yönetişimi, toplumda gücün nasıl kullanıldığını, toplumu etkileyen önemli kararların nasıl alındığını ve çeşitli çıkarların bu kararlarda nasıl yer aldığını belirleyen kurumları, süreçleri ve sözleşmeleri içeren bir olgu olarak değerlendirmektedir (Weiss, 2000, s. 797).

Tüm yönetişim tanımları arasında Küresel Yönetişim Komisyonu tarafından yapılan değerlendirme, en temsili ve kesin olanlardan biridir. 1995 yılında yayımlanan Küresel Komşuluk Komitemiz başlıklı bir araştırma raporunda komisyon, yönetişimi şu şekilde tanımlamıştır: "yönetişim, kamu ve özel sektörün, bireylerin ve kurumların ortak ilişkilerini yönetme biçimlerinin toplamıdır. Bu, birbiriyle çelişen veya farklı çıkarların yerine getirilebileceği ve işbirliğine dayalı işlemlerin başlatılabileceği sürekli bir süreçtir. Uyumun sağlanması için yetkilendirilmiş resmi kurum ve rejimlerin yanı sıra, insanların ve kurumların kendi çıkarlarına katılmayı kabul ettiklerini veya algıladıklarını belirten gayrı resmi düzenlemeleri de içerir. "Dört özelliği vardır: yönetişim bir kurallar veya etkinlik değil, bir süreçtir; yönetişim süreci kontrole değil, koordinasyona dayanır; hem kamu hem de özel sektörü içerir; resmi bir kurum değil, etkileşimi sürdürmektir (Keping, 2018, s. 2-3). 
1989 'da Afrika'da olanları özetlemeye çalışırken, Dünya Bankası ilk kez "yönetimde kriz" terimini kullanmıştır. O zamandan beri, bir kelime olarak yönetişim, özellikle sömürge sonrası ve gelişmekte olan ülkelerin siyasi durumunu tanımlamak için siyasi gelişim çalışmalarında yaygın olarak kullanılmaktadır. Çeşitli ülkelerden akademisyenler yönetişim teorisi ile ilgili genel olarak beş temel öneride bulunmuşlardır. Bunlar aşağıdaki gibidir (Keping, 2018, s. 2):

1. Yönetişim, hükümetin dışında ve ötesinde bir dizi kurum ve aktörü kapsamaktadır. Devletin veya hükümetin otoritesini geleneksel anlamda zorlayarak hükümetin, bir devletin tek güç merkezi olmadığını iddia eder. Bir kamu veya özel kuruluş tarafından kullanılan güç, halk tarafından tanındığı sürece, belirli bir düzeyde iktidar merkezi haline gelebilir.

2. Yönetişim, sosyal ve ekonomik sorunların üstesinden gelmek için sınırların ve sorumlulukların bulanıklığını ifade eder. Modern toplumda, devletin sorumluluklarını sivil topluma devrettiğini belirtir. Sonuç olarak, devlet ile toplum arasındaki ve kamu ile özel sektör arasındaki sınırlar, sorumluluklarının tanımları gibi giderek belirsizleşmektedir.

3. Yönetişim, kolektif eylemde yer alan kurumlar arasındaki ilişkilerde yer alan güç bağımlılığını tanımlar. Başka bir ifadeyle, kolektif eyleme adanmış her kuruluş diğer kuruluşlara bağlı olmak zorundadır. Amacına ulaşmak, kaynak alışverişinde bulunmak ve ortak bir hedef üzerinde görüşmek durumundadır. Değişimin sonucu sadece her oyuncunun kaynaklarıyla değil, aynı zamanda oyunun kuralları ve değişimin gerçekleştiği ortamla ilgilidir.

4. Yönetişim, özerk kendi kendini yöneten aktör ağlarının önemini vurgulamaktadır. Böyle bir özerk ağ, belli bir alanda emir verme ve bu alanda hükümetle birlikte çalışma ve kamu yönetimi için sorumlulukları paylaşma yetkisine sahiptir.

5. Yönetişim, komuta etmekte hükümetin yetkisini kullanma gücüne dayanmayan işlerin yürütülmesinde işleri yapma kapasitesini sağlar.

Osborne ve Gaebler'in, "Devletin Yeniden İcadı” (Reinventing Government) isimli çalışmaları kapsamında; girişimci yönetim (entrepreneurial government) yaklaşımı olarak en fazla atıf alan eserleri kamu örgütlerinin yapı ve çalışma pratiklerini on ilkeye dayandırmıştır. Buna göre kamu yönetimi, mal ve hizmet sunan birimler arasında tekeli arttırmak yerine rekabeti geliştirir; denetimi bürokrasiden topluma kaydırarak vatandaşları yetkilendirir; kurumlarda girdilerden çok çıktılara vurgu yaparak performans ölçümü yapar; kurumlar kural ve düzenlemelerden çok hedef ve misyonları esas alır; vatandaş yerine yeni ismiyle müşteriler alternatif hizmetler arasında seçenek kullanma hakkına sahip olur; problemler ortaya çıkmadan önlenilir; kamu örgütleri enerjilerini yalnızca para harcamak için değil, para kazanmak için de kullanır; katılımcı yönetim anlayışını benimseyerek otoritelerini desantralize ederler; bürokratik mekanizmalar yerine piyasa mekanizmaları tercih edilir ve toplumun kendi problemlerini çözmeleri için güçlendirilmesi söz konusu olur. Bu anlamda hükümet, tüm sektörlerin (kamu, özel ve gönüllü kuruluşlar) katılımını sağlamada katalizör görevi görmektedir (Osborne ve Gaebler, 1993, s. 25-310). 
Bürokratik Devlet anlayışından Girişimci Devlet’e geçişi öngören bu yaklaşımın esas aldığı nokta, özel sektöre ait toplam kalite yönetimi uygulamalarının kamu sektörüne transfer edilmesi ve bu çerçevede bürokraside girişimcilik ruhu oluşturmaktır. Siyaset-yönetim ayrımı kapsamında "Kürek çekmekten çok, dümen tutmak" felsefesi benimsenmektedir. Bu bağlamda devlet örgütlenmesinde ve işleyişinde rekabet, piyasalar, müşteriler, verimlilik gibi kavramlar eksene oturtularak devletin piyasalaştırılması, bir piyasa aktörü gibi özel sektörle rekabete girmesi öngörülmektedir. Girişimci devlet modeli üzerinden kamu yönetimine ilişkin örgütsel düzenlemeler Yeni Kamu İşletmeciliğinin ilkelerini muhafaza ederken, aynı zamanda Geleneksel Yönetim Anlayışı yerine devletin her düzeyi için geçerli olacak ve devlet-toplum ilişkisini yeniden düzenleyecek yeni bir model, "yönetişim modeli", önerilmektedir (Güzelsarı, 2004, s. 106-107).

Öte yandan "iyi yönetişim" kavramı da yönetişimi belli temel ilkeler üzerinden açıklamaktadır. Buna göre yönetişim, devletin ve piyasanın düzenleme ve koordinasyondaki belirli eksikliklerini telafi etme amacındadır. Birçok bilim adamı ve uluslararası kuruluş meta-yönetişim, nitelikli yönetişim, etkili yönetişim ve iyi yönetişim gibi çeşitli kavramlar ortaya koymuş ancak bunlardan en kabul göreni “iyi yönetişim” olmuştur (Keping, 2018, s. 4).

İyi yönetişimin ilkeleri; Meşruiyet ve ifade (Kadın ve erkeklerin meşru araçlar vasıtasıyla kararlara katılma kapasitesi ve fikir birliğinin sağlanması); Yönlendirme (Stratejik vizyon); Performans (Cevap verme sorumluluğu, etkinlik ve verimlilik yani kurumlar ve süreçler tüm paydaşlara hizmet etmeye çalışırken aynı zamanda ihtiyaçları karşılayan sonuçlar üretir); Hesapverebilirlik ve Şeffaflık (hükümet, özel sektör ve sivil toplum kuruluşlarındaki karar vericiler halka ve kurumsal paydaşlara karşı sorumludur. Süreçler, kurumlar ve bilgi kendileriyle ilgilenenlerin doğrudan ulaşabileceği ve onları anlamak ve izlemek için yeterli bilgi sağlanmaktadır); Eşitlik ve Tarafsızlık olarak ifade edilebilir (Graham vd., 2003, s. 3).

Yönetişim, YKI anlayışının 1990'lı yıllarda birçok ülkede başarısızıkla (enflasyon, işsizlik, yoksulluk sorununun devam etmesi) sonuçlanan reformlarının yeniden güncellenmesi ve devlet-piyasa karşıtlığı, optimal devlet yaklaşımlarının yerini devlet-piyasa dostluğu, etkin devlet, girişimci devlet gibi argümanlara bırakması şeklinde kendini göstermiştir. Yönetişim, kamu yönetiminde hükümetin yanı sıra özel sektör ve sivil toplum kuruluşlarının da önemli birer aktör olarak kararlara katılımını öngören bir anlayış oluşturmayı hedeflemiştir.

\subsection{Yeni Kamu Hizmeti (New Public Service)}

Yeni Kamu İşletmeciliği yaklaşımına bir tepki niteliği taşıyan Yeni Kamu Hizmeti Anlayışı; demokratik vatandaşlık, topluluk, sivil toplum, örgütsel hümanizm, yeni kamu yönetimi hareketi, post-modern kamu yönetimi gibi yaklaşımlardan hareket eden (Denhard and Denhard, 2007, s. 42), kendine özgü ilkeleriyle öne çıkan, Janet Denhardt ve Robert Denhardt tarafından kaleme alınan alternatif normatif bir modeldir. 
Kitabın önsözünde; iki temel amaçtan bahseden düşünürler, bu amaçlardan birincisinin, toplumsal menfaatlerin, demokratik değerlerin, vatandaşlığın ve kamusal hizmetin kamu yönetimi alanındaki normatif temeller olarak yeniden doğrulanmasını gerektiren birçok fikir ve sesi sentezlemek olduğunu; ikincisinin de, bu fikirleri belirli prensipler etrafında organize ederek, onlara bir isim ve eksik olduğu düşünülen unsurları önermek için bir çerçeve sağlamak olduğunu belirtmektedirler (Denhard and Denhard, 2007, s. xi).

Rasyonel seçim fikrine dayanan genel kamu yönetimi modelleri veya kamu işletmeciliği modellerinin aksine, Yeni Kamu Hizmeti alternatifini öneren yazarlar; (1) demokratik vatandaşlık teorileri, (2) topluluk ve sivil toplum modelleri, (3) örgütsel hümanizm ve yeni kamu yönetimi ve (4) postmodern kamu yönetimi gibi çağdaş öncüllere odaklandıklarını ileri sürmektedirler (Denhard and Denhard, 2007, s. 26)

Yeni Kamu Hizmeti Yaklaşımının temel ilkelerini Denhardt ve Denhardt, yedi madde olarak sıralamaktadır (2007, s. 42-43):

1. Müşteriye Değil, Vatandaşlara Hizmet Etme: Kamu yararı, bireysel çıkarların toplamından çok, paylaşılan değerlerle ilgili uzlaşmanın sonucudur. Bundan dolayı, kamu görevlileri yalnızca "müşterilerin" taleplerine cevap vermekle kalmamalı, vatandaşlar arasında güven ve işbirliği ilişkileri kurmaya odaklanmalıdır (Denhardt and Denhardt, 2007, s. 42).

2. Kamu Yararı Bir Amaçtır: Kamu yöneticileri, halkın çıkarına yönelik ortak, paylaşılan bir değer/fikir oluşturmaya katkıda bulunmalıdır. Amaç, bireysel seçimlerin yönlendirdiği hızlı ve basit çözümler bulmak değil, aksine ortak çıkar ve sorumluluğun oluşturulmasıdır.

3. Kamu Hizmeti, Girişimcilikten Değerlidir: Kamu yararı, kamu görevlilerince daha nitelikli sunulur. Vatandaşlar, kamunun parası kendilerinin olsa, girişimci yöneticilerden daha iyi bir şekilde topluma anlamlı katkılar yapma taahhüdünde bulunurlar.

4. Stratejik Düşünüp, Demokratik Davranmak: Kamusal politikalar ve programlar, ortak çabalar ve işbirlikçi süreçlerle toplumun intiyaçlarını en etkili ve sorumlu bir şekilde karşılamalıdır. Yeni Kamu Hizmeti, toplum için bir "vizyon" oluşturma sürecinin, yalnızca seçilen siyasi liderlere veya atanmış kamu yöneticilerine bırakılacak bir şey olmadığını talep etmektedir. Yeni Kamu Hizmeti, insanları toplumun alması gereken yönlerle ilgili sınırsız ve otantik söylemlere izin verecek ortamlarda bir araya getirme sürecinde hayati bir rol olarak görür. Bu müzakerelere dayanarak, toplum, devlet veya millet için geniş tabanlı bir vizyon oluşturulabilir ve gelecek için yol gösterici fikirler (veya idealler) sağlanabilir (Denhard and Denhard, 2007: 65).

5. Kamusal Sorumluluk/Hesap verebilirlik Basit Değildir: Kamu görevlileri, piyasadan daha çok yasalara ve anayasaya, topluluk değerlerine, siyasi normlara, mesleki standartlara ve vatandaş çıkarlarına özen göstermelidir. Hesap verebilirlik karmaşık bir konudur; sorunlara aktif vatandaşlık ve uzlaşma ile çözüm yolu aranmalıdır. Kamu yöneticisi, çatışan ve çelişen çıkar ve normları göz önünde bulundurarak kendine yol arar. 
6. Yönlendirmek Yerine Hizmet Etmek: Kamu görevlilerinin vazifesi, toplumu kontrol etmeye veya yönlendirmeye çalışmak yerine, vatandaşların ortak çıkarlarını ifade etmelerine ve karşılamalarına yardımcı olmaktır. Bunun için kamu yöneticilerinin vatandaşlar tarafından kabul edilen ortak, değere dayalı liderlik kullanmaları giderek daha fazla önem kazanmaktadır.

7. Sadece Verimliliğe Değil, Insana Değer Verilmeli: Kamu kurumları ve katıldıkları ağlar, tüm insanlara saygı temelinde işbirliği halinde faaliyet yürütürler. Bu anlayış, toplumun uygun gördüğü ortak bir liderlik süreciyle işletilirse uzun vadede başarılı olma ihtimalleri daha yüksektir.

Yeni Kamu Hizmeti (YKH) yaklaşımı, kamu yönetiminin odağının vatandaşlar, topluluklar ve sivil toplum olması gerektiği öncülüyle başlar. Kamu görevlilerinin birincil rolü, toplumu kontrol etmek veya yönlendirmek yerine vatandaşların ortak çıkarlarını ifade etmelerine ve karşılamalarına yardımcı olmaktır. Bu anlamda, kamu yöneticileri ve müşteriler arasındaki işlemlerin kişisel menfaatleri yansıttığı ve piyasa ilkeleri çerçevesinde gerçekleştiği gerekçesiyle YKi yaklaşımının felsefi öncülüne karşı çıkar. YKH, bürokrasiyle ilgili yukarıdan aşağıya politika oluşturma ve hizmet sunma mekanizmalarının, vatandaşların pasif kullanıcılar olarak muamele gördüğü eski kamu yönetimi yaklaşımından farklıdır. Yeni Kamu Hizmeti modeli, kamu yönetiminde aktif ve ilgili bir vatandaşlık kavramına dayanan, demokratik teorinin bakış açısına sahiptir. Kamu görevlilerinin rolü, toplumsal sorunlara cevap bulmada vatandaşların katılımını güçlendirmek için fırsatlar oluşturmaktır. Kamu yöneticileri, vatandaşlarla ortaklaşa bir şekilde karmaşık sorunları müzakere etmek ve çözmek için politika analizlerinin peşinde toplumu kontrol etme veya yönetme kapasitesinin ötesine geçen beceriler edinmelidir. Öte yandan daha geniş toplumsal ihtiyaçları ele almak ve kamu yararına uygun çözümler geliştirmek için hükümetlerin açık ve erişilebilir olmaları, hesap verebilir ve duyarlı olmaları, vatandaşlara hizmet etmeleri gerekir. Mevcut hesap verebilirlik biçimlerinden farklı olarak, devlet memurlarının seçilmiş memurlara, resmi görevlilere, vatandaşlara ve topluluklara karşı daha geniş sorumlulukları bulunmaktadır (Robinson, 2015, s. 10).

\subsection{Neo-Weberyen Devlet}

Ekonomik olmayan değerlere ve toplumsal sorunlara daha fazla önem vererek devletin meşruiyetini geri kazanmayı amaçlayan (De Vries, 2010, s. 3) Neo-Weberyen Devlet (NWD) kavramı; literatürde Pollitt ve Bouckaert'in 2004 yılındaki "Yeni Kamu İşletmeciliği: Karşılaştırmalı Bir Analiz" isimli eserine dayandırılmaktadır. Çalışmada Yeni Kamu İşletmeciliği perspektifli kamu yönetimi reformlarının ülkelerdeki uygulama örneklerinin sonuçlarının siyasi ve idari gelenek farklılıklarından dolayı benzer olamayacağı ileri sürülmüştür. Söz konusu eser, 2000, 2004 ve 2011 yıllarındaki basımlarıyla konuya ilişkin kavramsal ve teorik gelişimi ortaya koymaktadır. İlk baskıda 10 gelişmiş ülke karşılaştırmalı olarak analiz edilirken ikinci baskıda 2 ülke daha bu sayıya eklenmiştir. Çalışma kamu yönetimi reformlarının karşılaştııılması ve modelleştirilmesinin bir ürünü olarak değerlendirilebilir.

NWD'ye ilişkin ortaya atılan fikirler, genel olarak YKi'nin eleştirisi üzerinden şekillenmektedir. YKI'nin popülerliğinin azaldığı, başarısızlıklarının daha fazla olumsuzluk oluşturduğu, bundan böyle 
uygulanabilir bir model olarak değerlendirilemeyeceği; birçok konferansta ve çalışmada düşünürler tarafından açık bir biçimde dile getirilmiştir.

Pollitt ve Bouckaert, YKi’nin söylem ve uygulamasının birbiriyle örtüşmediğini dile getirmişlerdir. Resmi olarak ilan edilen politika, bu politikanın uygulamaya ne ölçüde yansıdığı ve istenilen sonucu verip vermediği arasında fark bulunduğunu belirtmektedirler. Onlara göre; YKi’nin ilkeleri her ülkede aynı şekilde görülmemiş ve sonuçları da aynı olmamıştır. Ülkelerin idari, siyasi, tarihsel ve kavramsal hafıza ve gelenekleri; kamu yönetimi reform ve uygulamalarının şekillenmesinde etkiye sahiptir (Çiner ve Olgun, 2015, s. 214-216). Dolayısıyla evrensel bir vizyondan bahsetmenin mümkün olmadığı söylenebilir.

Literatürdeki tartışmalara kapsamında NWD'in temel özellikleri aşağıda maddeler halinde sıralanmıştır (akt. Demir, 2018, s. 15):

- $\quad$ Neo Weberyen Devlet, vatandaşların talep ve beklentilerine bürokratik kurallardan daha fazla odaklanmayı kapsar. Piyasa mekanizmaları zaman zaman kullanışı olsa da, bunu başarmanın asıl yolu piyasa mekanizmalarını uygulamaktan değil profesyonel bir kalite ve hizmet kültürü yaratmaktan geçmektedir.

- $\quad$ Temsili demokrasinin rolünün, vatandaşların görüşlerine danışılarak ve bunların doğrudan temsil edilmesi aracılığıyla tamamlanmasını içerir.

- Hükümetin kaynak yönetimini gerçekleştirirken, yalnızca prosedürlere odaklanılmasından ziyade, sonuçların daha çok dikkate alınmasını sağlayacak şekilde ilgili kanunları güncellemesi öngörülmektedir. Bu, işlemlere yönelik önceden açık ve yazılı onay olmadan yapılan kontroller yerine işlemlerden sonra gerçekleştirilecek kontrollere önem verilmesi, fakat birincisinin de tamamen terk edilmemesi şeklinde ifade edilmektedir.

- Kamu hizmetlerinin profesyonelleştirilerek bürokratların sadece kendi faaliyet alanlarıyla ilgili mevzuatın uzmanı olmalarının önüne geçilmesi, vatandaşlar ve kullanıcıların ihtiyaçlarını karşılamaya yönelmiş profesyonel yöneticiler haline gelmeleri söz konusudur.

Pollitt ve Bouckaert, araştırmaları kapsamında 12 ülkede uygulanan idari reformları; Maintaining (Sürdürme/Koruma), Modernising (Modernleştirme), Marketising (Piyasacılaştırma) ve Minimising (Küçültme) olmak üzere 4M şeklinde sınıflandırmışlardır (Overman vd., 2015, s. 5-6).

Sürdürme/Koruma (Maintaining), aşamalı değişimi öngören yaklaşımı; Modernleştirme (Modernising), tüm yönetim fonksiyonları için performansa odaklanmayı; Piyasacılaştırma (Marketising), kamu sektöründe piyasa tipi mekanizmalara, zorunlu rekabete dayalı ihaleye, piyasa denemelerine, kıyaslama ve kupon gibi mekanizmalara yer vermeyi; Küçültme (Minimising), sözleşme yapma, taşeronluk, aktif ve pasif özelleştirmeyi amaçlamaktadır (Bouckaert, 2010, s. 5-6).

Daha genel ifadelerle açıklanırsa, "Sürdürme" anlayışına sahip olanlar, eski kamu yönetimi özelliklerini devam ettirmek isteyen, geleneksel kontrolleri sıkılaştıran, yeni alımları donduran, yönetim ve hukuk sistemini kısıtlayanlardır. "Modernleştiriciler", kamu yönetimini yenileme yolunu 
seçen, bütçelemede, yönetimde, kullanıcılarına hizmet götürmede esnekliği ve hızı tercih edenlerdir. "Piyasalaştırıcılar", piyasa merkezli argümanları kullanan, kamu örgütlerinin etkinliğini ve kullanıcı sorumluluğunu arttırmak için diğer kurumlarla rekabeti öngörenlerdir. "Minimalciler", olabildiğince çok görevi piyasaya özelleştirme ve ihale yoluyla devredenlerdir (Özsoy Özmen, 2016, s. 156).

Pollitt ve Bouckaert'e göre reform bağlamında dikkate alınacak iki ilgi grubu bulunmaktadır: Piyasalaştırıcı Anglo Amerikan YKi Çekirdek Grubu yani özel sektör yönetim tekniklerinin kamuda uygulanmasını savunanlar ve Kıta Avrupalı Modernleştiriciler diğer ismiyle devleti merkeze alanlar. Pollitt ve Bouckaert, bu ikinci Modernleştirici Grup reform modelini Neo Weberyen Devlet olarak tanımlamaktadır (Lynn, 2008, s. 1). Modernleştiriciler (NWD), devletin toplumun bütünleştirici unsuru olduğunu bundan dolayı pozisyonunun değiştirilemeyeceğini, ayrıca kamu yönetiminin, özel sektör uygulamalarına indirgenmesinin kabul edilemeyeceğini savunmaktadırlar.

Neo Weberyen Devlet anlayışının Weberci ve Neo'cu unsurları üzerinden değerlendirilmesi, kavramı daha anlaşıır kılacaktır. Buna göre Weberci unsurlar; "yeni sorunların çözüm mercii devlet olmalı, temsili demokrasi devlet teşkilatında yeniden güncellenmeli, idare hukukunun rolü uygun biçimde modernleştirilmeli, kamu hizmeti korunmalı" şeklindedir. Neo unsurlar ise; "bürokratik kurallar değil, vatandaş taleplerine önem verilmeli; temsili demokrasi kapsamında vatandaşlar danışma türü araçlarla desteklenmeli; süreç takibinden çok sonuçların başarısına odaklanmak için hukuki düzenlemeler yapılmalı; bürokrat, yalnızca mevzuat uzmanı rolüyle değil, vatandaşın ihtiyacını daha nitelikli karşılayan bir profile sahip olmalı" düşüncesine dayanmaktadır. Bu bağlamda NWD, devletin toplumda dümen tutma ve düzenleme yetkisi ile modernleşme, profesyonelleşme ve etkinlik sağlama olmak üzere iki boyutuyla öne çıkmaktadır (Çiner ve Olgun, 2015, s. 220-221).

NWD’nin yönetim kültürüne ilişkin en önemli savı, kamu yönetimine ilişkin bir reformun söz konusu olması halinde, ülkelerin yönetim kültürlerine dayanarak değişimin gerçekleştirilmesinin gerekliliğini vurgulamasıdır. Eğer böyle bir ilgi gösterilmezse, ülkelerde ortaya çıkacak sonuçların farklı olmasının kaçınılmaz olduğunun altı çizilmektedir.

\subsection{Kamu Değeri}

"Kamu değeri”, Mark Moore tarafından "Kamu Değeri Yaratmak: Kamuda Stratejik Yönetim" (Creating Public Value: Strategic Management in Government) isimli kitap çerçevesinde kamu yönetimi literatürüne giren bir kavramdır. Bu çalışmada esas alınan ana tema, kamu kurumlarının kamusal kaynakları, vatandaşlar tarafından değer verilen ve yararlanılan sonuçları kapsayacak şekilde kamu değeri oluşturmak için kullanmalarıdır. Bu bağlamda Mark Moore'un görüşüne göre, kamu yönetiminin özü "kamu politikalarını gerçekleştirmek ve uygulamak"tır. Belirli bir politik ve kurumsal ortamın görevi, "kamu değeri yaratma" olarak adlandırılan potansiyeli harekete geçirmek olmalıdır (Lynn, 2006, s. 27).

Kamu değeri kavramı, kamu yöneticilerinin görevlerini yerine getirirken vatandaşlar için bir değer üretip üretmediklerinin belirlenmesine cevap veren bir anlayıştır. Kamusal değer üretiminin 
bir tarafında kamu yöneticileri bulunurken diğer tarafında vatandaşlar vardır. Bu bağlamda kamusal değer üretme sürecine katkı verme hususunda yönetişim perspektifli uygulamalar önemli bir yere sahiptir. Kavramı literatüre kazandıran Moore, 1994 ve 1995 yıllarında yaptığı çalışmalarda kamu yönetimi ile işletme yönetimi arasındaki odak sorunsalının altını çizmiştir. İşletme yönetiminin odak noktasının kısa dönemde kâr, uzun dönemde marka değerini arttırmak iken; kamu yönetiminin kamusal değer üretimine odaklandığını belirtmektedir (akt. Karkın, 2012, s. 362-364).

Moore'a göre özel yöneticilerin hedefi özel (ekonomik) değer yaratmak olduğu gibi, devlet kurumlarının da hedefi "kamu (sosyal) değeri" oluşturmaktır. Kamu değerini neyin oluşturduğunu belirlemek ve üretmek için "kamu sektöründe strateji" kavramının altı çizilmektedir. Moore, bu fikrin sembolünü "stratejik üçgen" olarak adlandırdığı basit bir şema üzerinden açıklamaktadır. Şemanın amacı, hükümet yöneticilerinin dikkatini daha önce göz önünde bulundurmaları gereken üç karmaşık konuya odaklamak ya da kendilerini ve örgütlerini belirli bir hareket tarzına adamaktır. Bu üç husus aşağıdaki şekilde sıralanabilir (Moore and Khagram, 2004, s. 2):

$>$ Kuruluşun üretmeye çalıştığı önemli “kamu değeri” nedir?

$>$ Örgütün harekete geçmesine ve bu değeri yaratma çabasını sürdürmek için gerekli kaynakları sağlamasına izin vermek için hangi “meşruiyet ve destek kaynakları” olmalıdır?

$>$ Kuruluş istenen sonuçları sunmak için hangi “operasyonel kabiliyetleri” (yeni yatırımlar ve yenilikler dahil) kullanacaktır?

Kamu değerinin tanımı konusunda net bir açıklama vermeyen Moore, söz konusu tanımı kamu yöneticilerine bırakmıştır (Karkın, 2012, s. 364). Literatürde kavrama ilişkin tanımlama yapan düşünürlerin değerlendirmeleri üzerinden aşağıda çeşitli tariflere yer verilmiştir (akt. Köseoğlu ve Tuncer, 2014, s. 153):

a. Kamu değeri, sadece sonuçlar tarafından değil, aynı zamanda güven ve adalet oluşturabilen süreçler yoluyla üretilebilen çok boyutlu bir düzendir.

b. Kamu değeri; hizmetler, kanuni düzenlemeler ve diğer eylemler yoluyla devlet tarafından üretilen değerdir.

c. Kamu değeri, izlenmesi gereken bir ilkeyle veya hizmeti düzenlerken ya da üretirken kamu örgütleri tarafından karşılanması gereken bir standartla ilişkilendirilir.

d. Bir program veya politika için kamu değerinin üretilmesi, mevcut parasal ve yasal kaynaklar içinde halk için mümkün olan en iyi faydanın aranmasını kapsar. 
Teorik yönden kamu değeri; geleneksel kamu yönetimi, yeni kamu işletmeciliği ve ağ yönetişimi teorilerinin merkezinde yer almaktadır. Kamu değeri bir yönüyle yeni kamu işletmeciliğinin işletmecilik (managerialism), verimlilik ve performans ölçümü yaklaşımlarına ve geleneksel kamu yönetiminin meşruiyet, süreç yönetimi ve güven ilkelerine dayanırken, diğer yönüyle yönetişimin politika ve uygulama ağları yaklaşımlarını bütünleştiren ağ yönetişimi modeline yaslanmaktadır. Bu açıdan bakıldığında kamu değerinin amaçları bakımından ilkeli, ancak araçları bakımından pragmatist olan bu tavrı yeni kamu işletmeciliği sonrası döneme uygun olarak değerlendirilmektedir (Köseoğlu ve Tuncer, 2014, s. 159).

\section{Evrensel Kabul Edilen Teorilerin Adaptasyon Açmazı Olarak Yönetim Kültürü}

"Kültür" kavramı, toplum ve organizasyonlardaki aktörleri karşılıklı değerler, inançlar, bilişsel ve epistemik süreçler ve nihayetinde benzer davranışlara göre gruplamayı amaçlayan önemli bir unsurdur. Araştırmacılar bu gruplara odaklanmak suretiyle, öznel örgüt dünyasına erişmeye çalışırlar. Günümüzde kamu yönetimi araştırmalarında da, kültüre sosyal bir fenomen olarak yaklaşarak, bu konuda daha fazla bilgi oluşturma, özellikle uluslararası bir bilim için esas kabul edilmelidir (Schedler and Proeller, 2007, s. 189). Kültür çalışması, semboller ve anlamlar dünyasına, kuruluşların değer ve kalıplarına; dünyayı görmenin, yorumlamanın ve değerlendirmenin özel yollarına ilişkin oluşturulan davranışlara dikkat çeker. Kültürün bir yerden diğerine aktarılması söz konusu olduğunda; devlet aktörü ile sosyoekonomik ve politik faktörlerin yanı sıra dini kurumlar gibi sürece çeşitli aktörler de (bilinçli ve bilinçsiz olarak) katııırlar.

Tüm toplumsal kültürler gibi yönetim kültürleri de birbirinden farklıdır (Dwivedi, 2005, s. 21). Gelişmişlik seviyesine bakılmaksızın her ülkenin kendine özgü bir yönetim kültürü vardır ${ }^{3}$ İdarenin çalıştı̆̆ı genel sosyo-ekonomik ve politik ortam, kamu görevlileri üzerinde doğrudan bir etkiye sahip olduğundan onların tutumlarını, tarzını ve davranış biçimini şekillendirir. Yönetim kültürü bu yönüyle karmaşık bir fenomen olarak öne çıkmaktadır. Çünkü bugün yönetim kültürünü oluşturan parametreleri ve boyutları tanımlamak kolay gözükmemektedir. Yönetim kültürünün toplumsal kültürden farkıı bir şey olup olmadığını ya da sadece bir ülkenin kültürünün alt sistemi olduğunu söylemek bile zordur. Bir toplumun yönetim kültürünün belirlenmesinde dikkate alınması gereken parametreler arasında yönetici ve onun bakış açısı, dünya görüşü, kişisel ve örgütsel amaçlar hak-

\footnotetext{
${ }^{3}$ Rameshwor Dangal (2005), tarafından çalışılan Nepal'de Yönetim Kültürü başlıklı yüksek lisans tezinde; Nepal'deki toplumsal kültür ile yönetim kültürü arasında yakın ilişki olduğu tespit edilmiştir. Araştırmaya göre Nepal toplum kültürü; kast sistemi, aile yapısı ve nihayetinde idari sisteme yansıyan diğer inanç sistemleri tarafından belirlenmektedir. Nepal'deki mevcut kamu yönetiminde iki zorluk olduğu ileri sürülmektedir. Birincisi, egemen toplum kültürünün yönetim kültürünün şekillenmesindeki güçlü etkisi göz önüne alındığında, bu sektör nasıl reform edilebilir? İkincisi, kamu idaresinin kimliğini korumasını sağlamak için ne yapılmasının gerektiği; kalkınma ve vatandaşların ihtiyaçlarına cevap verme konusunda nasıl bir yöntemin izlenmesinin doğru olduğu üzerinedir.
} 
kındaki algısı, politik-idari çevre, toplumun sosyo-kültürel normları ve idealleri, vatandaşların taleplerine cevap verilme biçimi gibi unsurlar sayılmaktadır (Joshi, 2003).

Belirtilen yaklaşımlara rağmen sosyal bilimlerde kullanılan diğer pek çok kavram gibi, "yönetim kültürü" teriminin de her zaman tüm insanlar için aynı anlama gelmediği söylenebilir. Yönetim kültürünü inceleyen insanlar (farklı yerlerden veya coğrafi bölgelerden) tarafından farklı bakış açıları ve sonuçlar önerilebilir. Dwivedi (2005, s. 22) iki ana bakış açısının, bir ulusun yönetim kültürünü anlamaya yardımcı olabileceğini ileri sürmektedir. Birincisi, tüm ülkelerdeki devlet, yönetim kültürünü belirleme açısından birçok departmandan, ajanstan, şirketten oluşan tek bir organizasyon olduğundan daha geniş etki sahasına sahiptir. İkincisi, politikalar ve idari kararlar devlet aracıyla uygulandığından mali ve diğer kaynakların dağıtımında tüm toplum, yönetim kültüründen belirli şekilde etkilenir. Dolayısıyla devlet aygıtının davranışı, bir ülkede hüküm süren yönetim kültürüyle ilgilidir.

Yönetim kültürü, idari organizasyonların fiziksel imkanlarını ve kurumsal normlarını; personel tarafından paylaşılan ortak düşünceleri, değerleri, düşünce modelini, psikolojik durumu, davranış standardını ve yaşam tarzını birleştiren eşsiz bir kültür modeli olarak tanımlanmaktadır (Sun vd. 2014: 85). Hem tarihi ve politik faktörlerin toplamıdır; hem de siyasi ve yapısal güçlerin çağdaş etkileşiminin bir göstergesidir (Schedler and Proeller, 2007, s. 186).

Yönetim kültürüne ilişkin yapılan araştırmalarda dikkat edilmesi gereken hususları Dwivedi ve Nef, sekiz başlık altında sıralamaktadır (akt. Dwivedi, 2005, s. 21).

(1) Dünyanın herhangi bir yerindeki yönetim kültürü, çeşitli bölgesel, ulusal ve yerel gerçekliklerin farklılı̆ını ve karmaşıklığını yansıtır; benzersiz tarihi deneyimleri; bölgesel ve küresel ilişkiler sistemine yerleştirilme biçimleri; bunların gelişim ve parçalanma seviyeleri söz konusu kapsam içinde yer alır.

(2) Bu tür kültürler, geçmiş deneyimlerin, mitlerin ve geleneklerin model psikolojik yönelimleri şekillendirdiği tarihsel ürünlerdir.

(3) Herhangi bir yönetim kültürü, mevcut yapısal ve konjonktürel koşullar ve zorluklarla da şartlandırılır. Geçmişe dair algılara bile güncel deneyimler yöneltilir.

(4) Yönetim kültürü, fiziksel çevreye, ekonomiye, sosyal sisteme, politikaya ve kültüre yönelik değerler, uygulamalar ve yönelimler içeren geniş bir tutum matrisinin bir parçasıdır.

(5) Yönetim kültürü, tüm kültürler gibi, dinamik ve değişime açıtır. Uyarlama, süreklilik ve süreksizlik, onların yapısının bir parçasıdır.

(6) Bir yönetim kültürü, kültürlenme ve sosyalleşme sürecinin sonucudur.

(7) İdari reform ve "modernleşme" girişimlerinin çoğu doğrudan veya dolaylı olarak yönetim kültürü meselesine yöneliktir. Bu bağlamda herhangi bir radikal idari reform, önemli tutum ve değer değişiklikleri gerektirir. 
(8) Yönetim kültürü, küresel ve bölgesel eğilimlerden etkilenir.

Kamu yönetimi ve genel yönetim araştırmalarında çoğu bilim adamı, bir ülke veya bölgenin kültürü ile kamu sektörünün yapılandırıma ve işleyiş şekli arasında bir bağlantı olduğu konusunda hemfikirdir. Kamu yönetimi literatürüne bakıldığında, kültürün kamu yönetimi düzenlemeleri üzerindeki önemi ve etkisine yönelik özellikle "kültür" terimini "örgüt kültürü" olarak kullanmak suretiyle geniş bir kullanım ve atıfta bulunulduğu görülmektedir. Bu çalışmalar, kamu yönetimi mekanizmalarının yapı ve işleyişi üzerinde büyük etkisi olan kuruluşların, kuralların ve algıların oluşması konusunda geçmiş olayların ve bağlamların etkilerini vurgulamaktadır (Schedler and Proeller, 2007, s. 186).

Dreyfus, “Bürokrasinin İcadı: Fransa, Büyük Britanya ve ABD’de Devlete Hizmet Etmek (18.-20. yüzyıl)" isimli kitabında bürokrasiyi ayna metaforu üzerinden açıklamaktadır. Ona göre;

"bürokrasi, tarihinin her evresinde içinden çıktığı toplumu yansıtır. Bu durum, bürokrasinin dâhil olduğu siyasal tarihe geri dönmeyi; aynı zamanda da, iktidar biçimleriyle ilgilendiklerinden, idari sorunu kendi düşünme alanlarına dahil etmiş düşünce akımlarına; ve son olarak da, kurumsal uygulamaları yeniden biçimlendirmeye katkıda bulunan toplumsal dönüşümlere geri dönmeyi gerektirir" (Dreyfus, 2007, s. 26).

Kültür ve yönetim tarzı, bir ülkenin neyi, nasıl ve niçin yaptığını anlamanın anahtarı olduğundan, gelişmekte olan ülkelere uygulanan herhangi bir kamu sektörü reformunun, kültüre ve geleneklere dayanması gerekir. Üçüncü Dünya Ülkeleri için olduğu kadar Batı için de, adil ve sürdürülebilir bir dünyanın anahtarı, Batı kökenli paradigmaların ve yönetim kültürünün kendiliğinden ilan edilmiş evrensel önemi yerine düşünce ve eylemdeki çeşitliliği göz önünde bulundurmaktır. Ancak ortaya konulan yaklaşımlar, küreselleşme adına, gelişmekte olan ülkelerde Batı́nın fikirlerini ve kurumlarını nakletmeye ve çoğaltmaya vurgu yapan Batı tarzı yönetim teorisine ve metodolojisine belirli bir bağlıı̆̆ın devam ettiğini göstermektedir. Her yerde giderek daha fazla Batı değeri ve uygulaması yaygınlaştıkça, Batı'da geliştirilen göstergelere dayanan performans standartları ile birlikte, dünyanın geri kalanında taklit edici ve kopyalayıcı bir kamu yönetimi sistemi ortaya çıkmaktadır (Dwivedi, 2005, s. 33-34).

Lynn (2006), kamu yönetimine ilişkin reform süreçleri ve uygulamalarının; tarihi, kurumsal ve siyasal unsurlarla anlaşılabileceğini, ülkelerin tarihsel arka planı ve yönetim geleneklerinin kamu yönetimi reformlarının şekillenmesinde önemli bir yere sahip olduğunu ileri sürmektedir. Benzer şekilde Pollitt ve Bouckaert de ülkelerin kamu yönetimi reform ve uygulamalarının biçimlendirilmesinde ülkelerin idari, siyasi, tarihi gerçekliklerinin göz ardı edilemeyeceğini vurgulamaktadırlar. Hood (2010, s. 1), çağdaş yönetim kuramcılarına vurgu yaparak, her bir toplumun makro yönetsel düzenlemelerinin kendine özgü kültürel, kurumsal ve güç dağıtımı özelliklerine dayandığını ifade etmektedir. 
YKi uygulamaları üzerinden bir perspektif çizilecek olunursa; reform pratiklerine bakıldığında, uygulamada çok fazla çeşitlilik olduğu göze çarpmaktadır. 30 yıldan fazla bir süredir Yeni Kamu İşletmeciliği, kamu sektörü reformu için en popüler yaklaşımlardan biri olmuştur. Bununla birlikte, 15 yıldan uzun bir süredir Yeni Kamu İşletmeciliği ağır bir şekilde eleştirilmekte hatta bir kısım düşünürler tarafından "ölü" olarak kabul etmektedir (Reiter and Klenk, 2019, s. 11). Ancak yine de peşin hükümden uzak durarak Dunleavy ve diğerlerinin 2005'te yazdıkları makaleleriyle sordukları "Yeni Kamu İşletmeciliği Öldü mü?" sorusuna, De Vries (2010, s. 5)'ın ifade ettiği gibi "gerçekten ölmedi ancak başı belada" demenin uygun olduğu söylenebilir. Çünkü YKí, bazı ülkelerde başarılı sonuçlara sahne olurken, kimi ülkelerde de olumsuz netice vermiştir. Pollitt ve Bouckaert'ın, "Public Management Reform: A Comparative Analysis - NPM" (Kamu Yönetimi Reformu: YKi Karşılaştırmalı Bir Analiz) başlıklı makalelerinde YKi ilkelerinin ülkelerdeki uygulama ve sonuçlarının benzer olmadığı bu kapsamda reform süreçlerinde ülkeler arası farklılı̆a dikkat çektikleri görülmektedir (Schedler and Proeller, 2007, s. 187). Bunun temel nedeni; ülkelerin sahip olduğu farklı özellikleri, kendilerine özgü politik rejimleri, örgütsel ve kurumsal kültürleriyle açıklanmaktadır (De Vries, 2010, s. 3).

\section{Sonuç}

Batıdaki sosyal bilimlerin hakim görüşü çerçevesinde şekillenen küresel olarak kurumsallaşmış dünya düzeni, kendi içerisinde yaşadığı krizi diğer ülkelere de yansıtmaktadır. "Batı dışı toplumlar"a kalıp biçen sömürgecilik düşüncesinin ürettiği oryantalizm, evrensellik ve bağımlılık tezlerinin söz konusu hakimiyet alanı içinde geliştiği açıktır. Batı kapitalizminin aracı olan ve insanı değersizleştiren "bürokrasi, yönetim ve örgüt teorileri” yalnızca bilim dünyasıyla sınırlı kalmamış, zihin dünyasını da etkisi altına almıştır. Sözgelimi Maslow'un ìntiyaçlar Hiyerarşisi, evrensel bir vurguyla insanı ancak karnını doyurup maddi ihtiyaçlarını temin ettikten sonra kendisini gerçekleştirebilir bir varlık olarak tanımlar. Ancak vatan savunması için cepheye götürdüğü silahların ıslanmaması için çocuğunun yerine silahların üzerini örten annenin davranışını açıklayamaz. Max Weber'in bugün bile yürürlükte olan Bürokrasi Teorisi, nesnel ve tarafsız bir yönetimi sağlamaya çalışırken insana güvenmez; insani olan değer yargılarını reddeder; üstü astına tartışmasız hakim kılar; üst düzey amir, bilimsel bilgiye dayalı otoritesine aşırı bir güven duyduğundan hata yapmayacağını varsayarak karar alır. Oysa bu teori; Türk-İslam Siyasetnamelerindeki "ne kadar emin olursan ol, mutlaka istişare et" düsturu ile örtüşmemektedir. Weber'de insan aklına mutlak güven düşüncesi, Türk-i̇slam Siyasetnamelerinde tedirginlikle ve temkinle karşılanır ve çaresi de hükümdarın azamet ve ihtişamına rağmen nefsini kırıp istişare etmesidir.

Kültür, bir toplumun üyelerinin ortak olarak paylaştıkları ve gelecek kuşaklara ilettikleri bilgi, görgü, inanç, değer, davranış, alışkanlık gibi ögelerdir. Toplumda sosyal ve siyasal ilişkilerin örgütlenmesi kültüre dayanır. Yaşam biçiminden düşünme şekline, konuları kavramsallaştırmadan olaylara anlam yükleyebilmeye kadar kültür etkilidir. Bu bağlamda kültürün toplumları birbirinden ayıran önemli bir ölçüt olduğu söylenebilir. Bir toplumun kültürü; o toplumun sanatını, edebiyatını, siyasetini, yönetimini de şekillendirir. Bir organizasyonda değişimin başarılı olması için toplumsal kültür ve yönetim kültürünün buna uygun olması gerekmektedir. Stratejik planlar Türkiye'de çok iyi 
bir şekilde algılanmamış, bir dayatma gibi hissedilmiştir. İstisnalar olmakla birlikte yeni planlar eski plana göre yeniden uyarlanmaktadır. Kurumlar daha önceki yıllarda yapmış oldukları hedefleri, stratejik plan konsepti içinde bir performans olarak ortaya koymuşlardır. Stratejik plana ilişkin yapılan araştırmaların sonucunda belirtildiği gibi, üst idari makamların stratejik plan sürecini sahiplendiklerini, destek vereceklerini belirtmesinin çalışanların planlama sürecine yaklaşımlarını etkilememektedir. Bu bağlamda ülkelerin ulusal ve yönetsel kültürleri incelenmeden idari, siyasi, ekonomik ve sosyal sistemde değişiklik yapmak toplumsal ve bürokratik dirençle karşılaşabilir. Çünkü Türkiye'de kamu kurumlarında performansın algılanma biçimiyle ABD'deki idrak edilme şekline bakıldığında ortak bir anlayış olmadığı görülür. Türkiye'de kamu görevlilerinin performans değerlendirmesinden anladığı, ilgili periyotta daha önceki başarımının üstüne ne koyacağı değil, o dönem ne yapacağının önceden söylenmesinden ibarettir. Değişime ilişkin ortak zihinsel modelin olmamasından kaynaklanan bir sonuçtur bu. Yönetişim için de benzer ifadeler kullanılabilir. Yönetişimle merkeziyetçi bir geleneğe sahip olan Türkiye'de devlet dışı aktörlerin kamusal görevlerde belirleyici olması beklenmektedir. Kamu yönetimine, özel çıkarı temsil eden özel sektör kuruluşları ve çıkar grubunu ifade eden sivil toplum örgütlerinin aktif bir özne olarak dahil olmaları halinde kararın vatandaşlar tarafından daha meşru karşılanacağı düşünülmektedir. Ancak uygulamada yönetişimi, siyaset ve bürokrasi mekanizması görüş alışverişi yapılan yapılar olarak algılamakta ve son kararı devlet mekanizması vermektedir. Zira Türkiye'de, devletin kamu yararını tesis edeceği inanc hakimdir. Dolayısıyla yönetim kültürü belli bir yönetsel model veya kurguyla adapte olmaya uygun değilse değişim yavaş veya sıkıntılı olur.

Kamu görevlileri, kör bir şekilde belli politikaları uygulayan robotlara benzetilemez. Kamu bürokrasisinde her bir örgütün üyelerinin ortak değerleri vardır. Elbette koşullar değiştikçe yeni düzenlemeler ve kurumlar kaçınılmazdır. Ancak ilgili toplumun yönetim kültürü ile daha kolay bütünleşme sağlayacak, değerleriyle, davranış örüntüleriyle uyumlu bir model tercih edilmelidir. YKi kapsamında daha az bürokratik yapı ile daha az bürokratik sorun yaşanması beklentisi, kamuoyuna müşteri muamelesi yapma, sonuç odaklılık, sözleşme yapma gibi unsurlar özel sektör uygulamalarının etkisiyle dar bir alanın içine hapsedilmiştir. Bu uygulamaların ülke değerlendirmeleri üzerinden sonuçlara yansıyan yönüne bakıldığında başarı ve başarısızlığın yönetim kültürüne göre dağılması rastlantı değildir.

\section{Kaynaklar}

Aucoin, Peter (1990). "Administrative Reform in Public Management: Paradigms, Principles, Paradoxes and Pendulums", Governance: An International Journal of Policy and Administration, Vol. 3, No. 2, pp. 115-137.

Bouckaert, Geert (2010). "New Public Leadership for Public Service Reform", Comparative Administration Change: Lessons Learned, (Ed. Jon Pierre and Patricia W. Ingraham), McGillQueens's University Press, London, pp. 51-66. 
Burns, Tom (1980). "Sovereignty, Interests and Bureaucracy in the Modern State", The British Journal of Sociology, Vol. 31, No. 4, pp. 491-506.

Carneiro, Robert L. (1970). "A Theory of the Origin of the State", Science, Vol. 169, https://eml.berkeley.edu/ saez/course/carneiro70.pdf

Chevallier, Jacques (1996). "Public Administration in Statist France", Public Administration Review, Vol. 56, No. 1, pp. 67-74.

Çiner, Can Umut ve Burcu Olgun (2015). "Neo-Weberyen Devlet: Yeni Kamu İşletmeciliği İçin Bir Tartışma”, Kamu Yönetiminde Paradigma Arayışları: Yeni Kamu İşletmeciliği ve Ötesi, (Ed. Özer Köseoğlu ve Mehmet Zahid Sobacı), Dora Basım Yayın, Bursa, ss. 205-230.

Dangal, Rameshwor (2005). Administrative culture in Nepal: does it reflect the dominant sociocultural values of Nepal?, The University of Bergen, Department of Administration and Organization Theory Master Thesis, Nepal.

De Vries, Jouke (2010). “Is New Public Management Really Dead?”, OECD Journal on Budgeting, Vol.1, pp. 1-5.

Demir, Fatih (2018). “Avrupa Birliği'nde Kamu Yönetimi Reformları Üzerine Bir Değerlendirme”, ASSAM Uluslararası Hakemli Dergi (ASSAM-UHAD), C. 5, S. 12, ss. 10-20.

Denhardt, Janet V. and Robert B. Denhard (2007). The New Public Service: Serving, Not Steering, Expanded ed, M.E. Sharpe, New York.

Dreyfus, Françoise (2007). Bürokrasinin İcadı: Fransa, Büyük Britanya ve ABD’de Devlete Hizmet Etmek (18. - 20. Yüzyıl), İletişim Yayınları, İstanbul.

Dwivedi, O. P. (2005). Administrative Culture and Values: Approaches", Administrative Culture in a Global Context, (Eds. J. G. Jabbra and O. P. Dwivedi), De Sitter Publications, Ontario, Canada, pp. 19-36.

Ergun, Turgay (1997). “Postmodernizm ve Kamu Yönetimi”, Amme İdaresi Dergisi, C: 30, S: 4, ss. 316.

Eryılmaz, Bilal (2018). Kamu Yönetimi, Umuttepe Yayınları, 11. Baskı, Kocaeli.

Graham, John, Bruce Amos and Tim Plumptre (2003). "Principles for Good Governance in the 21st Century", Policy Brief No. 15: Institute On Governance, Ottawa, Canada, 1-6., http://unpan1.un.org/intradoc/groups/public/documents/UNPAN/UNPAN011842.pdf

Gruening, Gernod (2001). “Origin and theoretical basis of New Public Management”, International Public Management Journal, Vol. 4, 1-25.

Güzelsarı, Selime (2004). "Kamu Yönetimi Disiplininde Yeni Kamu İşletmeciliği ve Yönetişim Yaklaşımları", Kamu Yönetimi Gelişimi ve Güncel Sorunlar, (Ed. M. Kemal Öktem ve U. Ömürgönülşen), İmaj Yayınevi, Ankara. 
Hood, Christopher (1991). "A Public Management For All Seasons?”, Public Administration, Vol. 69, No. 1, pp. 3-19.

Hood, Christopher (2000). "Paradoxes of public-sector managerialism, old public management and public service bargains", International Public Management Journal, Vol. 3, pp. 1-22.

Joshi, Preeta (2003). "Accountability, Indian Administrative Culture and Trust", Public Administration: Challenges of Inequality and Exclusion Miami (USA), 14-18 September 2003, http://unpan1.un.org/intradoc/groups/public/documents/iias/unpan011171.pdf, e.t.: 15.08.2019

Karkın, Naci (2012). “Kamu Siyasalarının Üretilmesinde Yeni Bir Ölçüt: Kamusal Değe Kavramı ve Kritiği”, Kayfor 2012 Bildiriler Kitabı, TODAiE Yayınları, Ankara, ss. 359-372.

Keping, Yu (2018). "Governance and Good Governance: A New Framework for Political Analysis", Fudan J. Hum. Soc. Sci., Vol. 11, pp. 1-8.

Köseoğlu, Özer ve Aziz Tuncer (2014). Kamu Yönetiminde Yeni Bir Yaklaşım Olarak Kamu Değeri: Kavramsal ve Kuramsal Açıdan Bir Tartışma”, Yönetim Bilimleri Dergisi, C. 12, S. 24, ss. 145170.

Leblebici, Doğan N. (2001). “Disiplin ve Uygulama Açısından Kamu Yönetiminin 'Kimlik Krizine' Yeni Bir Bakış”, C.Ü. Sosyal Bilimler Dergisi, C: 25, S: 1, ss. 15-24.

Leblebici, Doğan N. (2004). “Kamu Yönetimi: Dünya'da ve Türkiye'deki Gelişimi”, Ed. M. Kemal Öktem ve Uğur Ömürgönülşen, Kamu Yönetimi: Gelişimi ve Güncel Sorunları, İmaj Yayınevi, Ankara.

Livioara, Goga Gina (2009). "Bureaucratic Administration in Modern Society", European Integration Realitites and Perspectives Proceedings, Vol. 4, No. 1, pp. 127-136.

Lynn, Laurence E. (2006). Public Management: Old and New, Routledge, New York.

Lynn, Laurence E. (2008). "What Is a Neo-Weberian State? Reflections on a Concept and Its Implications", (Ed. Christopher Pollitt, Geert Bouckaert, Tiina Randma-Liiv, Wolfgang Drechsler), The NISPAcee Journal of Public Administration and Policy, Special Issue: A Distinctive European Model? The Neo-Weberian State, 1(2), Winter 2008/2009, 17-30.

Maesschalck, Jeroen (2004). “The Impact of New Public Management Reforms on Public Servants' Ethics: Towards a Theory”, Public Administration, Vol. 82, No. 2, 465-489.

Moore, Mark H. and Sanjeev Khagram (2004). “On Creating Public Value: What Business Might Learn from Government About Strategic Management", https://www.corporation2020.org/corporation2020/documents/Papers/SF Prep/Khagram.p df, E.T. 10.09.2019. 
Nişancı, Zehra Nuray (2015). "Geçmişten Günümüze Yönetim Düşüncesi”, Yönetim Bilimleri Dergisi, C. 13, S. 25, ss.257-294.

Osborne, David and Ted Gaebler (1993). Reinventing Government: How The Entrepreneurial Spirit Is Transforming The Public Sector, A Plume Book, New York.

Overman Sjors, Mrieke van Genugten, Sandra Van Thiel (2015). “Accountability After Structural Disaggregation: Companing Agency Accountability Arrangements", Public Administration, 93(4), pp. 1-24.

Özer, M. Akif (2014). "Kamu Yönetiminde Değişim Sürecini Dwight Waldo ile Yeniden Düşünmek", Amme İdaresi Dergisi, C. 47, S. 4, ss.1-30.

Özgür, Hüseyin (2003). "Yeni Kamu Yönetimi Hareketi”, (Ed. M. Acar ve H. Özgür), Çağdaş Kamu Yönetimi I, Nobel Yayın Dağıtım, Ankara, ss. 183-224.

Özgür, Hüseyin ve Mısra Ciğeroğlu Öztepe (2015). “Amerikan Yeni Kamu Yönetimi Hareketi (YKYH): Sosyal Adalet ve Hakkaniyet Odaklı Bir Kamu Yönetimi Arayışı", Kamu Yönetiminde Paradigma Arayışları: Yeni Kamu İşletmeciliği ve Ötesi, (Ed. Özer Köseoğlu ve Mehmet Zahid Sobacı), Dora Basım Yayın, Bursa, ss. 97-127.

Özsoy Özmen, Arzu (2016). Türkiye'de Kamu Çalışma Illişkilerinde Güvencesizlik: Uyum ve Direniş Örüntüleri, Kocaeli Üniversitesi SBE Yayımlanmamış Doktora Tezi, Kocaeli.

Parlak Bekir ve Kadir Caner Doğan (2016). Kamu Yönetimi: Kamu Yönetimi Disiplininin Gelişmesinde Rol Oynayan Kuramsal Yönler Üzerine Bir Giriş, Beta Yayınları, İstanbul.

Petersen, Michael Bang and Svend-Erik Skaaning (2010). "Ultimate Causes of State Formation: The Significance of Biogeography, Diffusion, and Neolithic Revolutions", Historical Social Research, Vol. 35, No. 3, pp. 200-226.

Pfiffner, James P. (2004). "Traditional Public Administration versus The New Public Management: Accountability versus Efficiency", Institutionenbildung in Regierung und Verwaltung: Festschrift fur Klaus Konig, (eds. A. Benz, H. Siedentopf, and K.P. Sommermann), Duncker \& Humbolt, Berlin, pp. 443-454. http://pfiffner.gmu.edu/files/pdfs/Book Chapters/NewPublicMgt.doc.pdf, E.T. 16.08.2019

Reiter, Renate and Tanja Klenk (2019). "The manifold meanings of 'post-New Public Management' - a systematic literature review", International Review of Administrative Sciences, Vol. 85, Is. 1, pp. 11-27.

Robinson, Mark (2015). From Old Public Administration to the New Public Service: Implications for Public Sector Reform in Developing Countries, UNDP Global Centre for Public Service Excellence, Singapore.

Sayman, Coşkun (2006). Dwight Waldo ve Yönetim Yazını, Ankara Üniversitesi Sosyal Bilimler Enstitüsü, Yayımlanmamış Yüksek Lisans Tezi, Ankara. 
Schedler, Kuno and Isabella Proeller (2007). "Public Management As A Cultural Phenomenon: Revitalizing Societal Culture In International Public Management Research", International Public Management Review, Vol. 8, Is. 1, pp. 186-194.

Spicer, Michael W. (1998). "Cameralist thought and Public Administration", Journal of Management History, Vol. 4, Is. 3, pp.149-159.

Sun Zhuo-hua, Chen Jing, Li Qiang-Nan (2014). “Analysis of Administrative Culture Research from the Aspect of Bibliometrics", 3rd International Conference on Science and Social Research (ICSSR 2014), Published by Atlantis Press, 85-89. https://download.atlantis-press.com > article, e.t.: 13.08 .2019

Tarhan, Ahmet Bora ve Erhan Ezici (2011). "Kamu Hizmetlerinin Üretiminde Yeni Kamu Yönetimi Anlayışı Ve Toplam Kalite Yönetimi”, Sosyal ve Beşeri Bilimler Dergisi, Cilt 3, No 2, 13-21.

Tatulescu, Alina (2013). "An Overview of the Main Theories Regarding the Role of the State", Economic Insight-Trends and Challenges, Vol. 2, No. 4, pp. 73-82.

Thornhill C. and G. Van Dijk (2010). "Public Administration Theory: Justification for Conceptualisation", Journal of Public Administration, Vol. 45, No. 1, pp. 95-110.

Weiss, Thomas G. (2000). “Governance, Good Governance and Global Governance: Conceptual and Actual Challenges", Third World Quarterly, Vol. 21, No. 5, pp 795-814. 